\title{
Sectoral assessment of greenhouse gas emissions in Pakistan
}

\author{
Kaleem Anwar Mir ${ }^{1}$, Pallav Purohit ${ }^{2}$, Shahbaz Mehmood ${ }^{1}$ \\ ${ }^{1}$ Global Change Impact Studies Centre (GCISC), Ministry of Climate Change, Islamabad, Pakistan. \\ ${ }^{2}$ International Institute for Applied Systems Analysis (IIASA), Laxenburg, Austria.
}

Corresponding author Email: kaleemanwar.mir@gmail.com

Telephone number: +923015465960

\begin{abstract}
In this study, an attempt has been made to develop inventory of greenhouse gas (GHG) emissions for Pakistan at the national and sectoral level. The emission profile includes carbon dioxide $\left(\mathrm{CO}_{2}\right)$, methane $\left(\mathrm{CH}_{4}\right)$ and nitrous oxide $\left(\mathrm{N}_{2} \mathrm{O}\right)$. In 2012, GHG emissions from different sectors of economy are

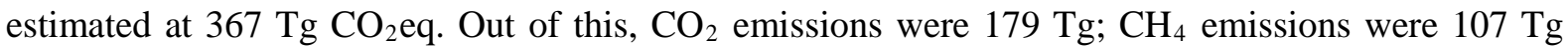
$\mathrm{CO}_{2}$ eq; and $\mathrm{N}_{2} \mathrm{O}$ emissions were $81 \mathrm{Tg} \mathrm{CO}_{2}$ eq. Energy and agriculture sectors contribute approximately 89 percent of national GHG emissions. Industrial processes, waste, land use change and forestry (LUCF) sectors contribute the remaining 11 percent GHG emissions. A comparison with the 1994 GHG emission inventory of Pakistan shows that GHG emissions in Pakistan from 1994 to 2012 have increased at an annual growth rate of 4.1 percent and yet anticipated to increase further for meeting the national developmental goals, however, the per capita emissions in Pakistan will remain low when compared with the global average.
\end{abstract}

Key-words: Greenhouse gas inventory; fossil fuel combustion; industrial processes; waste; agriculture; land use change and forestry (LUCF) 


\section{Introduction}

Global climate change is a major issue confronting policymakers worldwide. The underlying cause is the increasing concentration of carbon dioxide $\left(\mathrm{CO}_{2}\right)$ and other non- $\mathrm{CO}_{2}$ greenhouse gases $\left(\mathrm{CH}_{4}, \mathrm{~N}_{2} \mathrm{O}\right.$, HFC, PFCs and $\mathrm{SF}_{6}$ ) in the atmosphere due to ever increasing use of fossil fuels since the advent of the industrial revolution in the $18^{\text {th }}$ Century and increased agricultural activities associated with the growing world population (Seinfeld and Pandis, 2006). In 2011, the atmospheric concentration of $\mathrm{CO}_{2}$ exceeded its pre-industrial level by about 40 percent (Tian et al., 2016). Since global warming is the main driver of climate change, the United Nations Framework Convention on Climate Change (UNFCCC) is striving hard for not allowing the global average temperature to rise beyond $2^{\circ} \mathrm{C}$ above the pre-industrial level in order to prevent unmanageable adverse impacts of climate change. In this regard Kyoto Protocol, with binding commitments by industrialized countries to reduce their greenhouse gas (GHG) emissions, was signed in 1997 and came into force in 2005. During the first commitment period (20082012), 37 industrialized countries and the European Community committed to reduce GHG emissions to an average of 5 percent against 1990 levels. However, these targets were not satisfactorily achieved (Grunewald and Martinez-Zarzoso, 2016; Aichele and Felbermayr, 2013). Recently, the UNFCCC at its $21^{\text {st }}$ Conference of Parties (COP-21), have yielded an international agreement (called the Paris Climate Agreement) vowing to hold warming well below $2^{\circ} \mathrm{C}$, and attempting to limit it to $1.5^{\circ} \mathrm{C}$ (Rogelj, 2016). Certainly this is a step forward and the ambitious nature of the agreement is commendable but the actual work has yet to begin.

An essential element of the UNFCCC effort for stabilizing GHG concentrations and to prevent reaching unmanageable levels of climatic changes is to have a systematic record of the GHG emissions of countries so that their time trends may be properly monitored. As per Article 4 (paragraph 1a), and Article 12 (paragraph 1a) of the UNFCCC, it is required for all non-Annex I parties (primarily developing countries) to prepare and convey a national GHG emission inventory to the Conference of the Parties by following the guidelines described in Annex to decision 17/CP.8 (UN, 1992).

In order to contribute towards this objective, the Government of Pakistan (GoP) worked out its GHG emissions inventory for the year 1994 covering various socio-economic sectors as per guidelines of 
Intergovernmental Panel on Climate Change (IPCC) and submitted it along with its Initial National Communication to UNFCCC in 2003 (UNFCCC, 2003a). In this study, we assess the GHG emissions (including $\mathrm{CO}_{2}, \mathrm{CH}_{4}$ and $\mathrm{N}_{2} \mathrm{O}$ ) as a result of anthropogenic activities from various sectors [energy, agriculture, industrial processes, waste, land use change and forestry (LUCF)] of the economy at national level for the year 2012. The estimates of the collective emissions of $\mathrm{CO}_{2}, \mathrm{CH}_{4}$ and $\mathrm{N}_{2} \mathrm{O}$ are expressed as carbon dioxide equivalent $\left(\mathrm{CO}_{2} \mathrm{eq}\right)$. For this purpose, the global warming potential (GWP) of $\mathrm{CO}_{2}, \mathrm{CH}_{4}, \mathrm{~N}_{2} \mathrm{O}$ has been taken as 1, 21 and 310, based over a 100-year time horizon given in IPCC Second Assessment Report, in line with the guidelines contained in Annex to decision 17/CP.8 (UNFCCC, 2003b).

This paper begins with outlining the methodology used to assess GHG emissions in Section 2. Section 3 presents activity data used and results of sectoral distribution of GHG emissions by source. Section 4 analyze the development of GHG emissions in Pakistan as compared to the 1994 GHG inventory along with description of mitigation flexibility in various source sectors. This paper then concludes by highlighting some concerns and uncertainties associated with the development of GHG inventory for Pakistan (Section 5).

\section{Methodology, activity data and emission factors}

The Revised 1996 IPCC Guidelines methodology along with UNFCCC non-Annex I National Greenhouse Gas Inventory Software, Version 1.3.2 has been used for estimating the GHG emissions from various sectors. In these estimates, tier-1 approach of Revised 1996 IPCC Guidelines has been used by taking into consideration the data availability and national circumstances in Pakistan. Tier 1 techniques are intended to be the least complex to utilize and require country-specific activity data and IPCC default emission factor values. In general, moving to higher tiers enhances the inventory's accuracy and lessens uncertainty, but in the meantime the resources and complexity necessary for conducting such emission inventories also increases. Therefore, tiers 2 and 3 or combination of tiers are not followed at this time because of the; unavailability of country- or region-defined emission factors data; absence of models and inventory measurement systems fitted to national conditions, repeated over time, and driven by high-resolution activity data and disaggregated at the sub-national level. The main 
data sources used in this inventory are Pakistan Energy Year Book 2012, Agricultural Statistics of Pakistan 2012 and Pakistan Economic Survey 2014 (MoF, 2014; HDIP, 2013; MoNFSR, 2012).

The description of simplest methodology employed for the estimation of emission of a specific GHG from all source categories involves the multiplication of source category activity data with the corresponding emission factor. Furthermore, for assessing total GHG emissions, all individual source category emissions are summed as presented below:

$$
\mathrm{E}_{\mathrm{GHG}}=\Sigma_{\text {Category }} \mathrm{A} \times \mathrm{EF}
$$

Here, $\mathrm{E}_{\mathrm{GHG}}$ is the emissions of a given $\mathrm{GHG}\left(\mathrm{CO}_{2}, \mathrm{CH}_{4}\right.$ or $\left.\mathrm{N}_{2} \mathrm{O}\right)$ from all its source categories, $\mathrm{A}$ is the activity data i.e. the amount of individual source category utilized that generates emissions of the GHG under consideration, EF is the emission factor of a given gas by type of source category (emissions per unit of activity data utilized) (IPCC, 1997).

Table 1 presents the sectoral classification for GHG emission inventories for all sectors. This study uses the default emission factors for estimating $\mathrm{CO}_{2}$ emissions published in IPCC (1997) known as Revised 1996 IPCC Guidelines for national greenhouse gas inventories for categories and gases because country specific factors are not available for Pakistan (Table S1 of the supplementary section). Likewise, non$\mathrm{CO}_{2}$ default emission factors published in IPCC (1997) has been used to estimate non-CO $\mathrm{CO}_{2}$ emissions $\left(\mathrm{CH}_{4}\right.$ and $\left.\mathrm{N}_{2} \mathrm{O}\right)$ from various source categories. The activity data for the year 2012 have been mainly obtained from the available documents of different organizations and ministries of the Government of Pakistan (GoP) particularly the Ministry of Petroleum and Natural Resources (MoPNR), Ministry of Finance (MoF), Pakistan Bureau of Statistics (PBS) and Ministry of National Food Security and Research (MoNFSR) (HDIP, 2013; MoF, 2013; MoNFSR, 2012).

\section{Results and discussion}

\subsection{Activity data by sector}

Pakistan being located in South Asia is the sixth-most populous country with a population above 199 million people in 2015 (CIA, 2016). The gross domestic product (GDP) of Pakistan at purchasing power parity (PPP) was US\$ 931 billion in 2015. The growth in real GDP has been estimated at 3.5 percent 
for the period 2008-2014, while the annual per capita GDP at PPP was estimated at US\$ 5000 (CIA, 2016). Pakistan’s energy needs have been rising speedily every year since 1990 following an industrial revolution. In the past 19 years, the consumption of primary energy in Pakistan is almost doubled i.e. from 34 million tons of oil equivalents (Mtoe) in 1994-1995 to 67 Mtoe in 2013-2014 (MoPDR, 2015). Though Pakistan is not anticipated to play a key role in global warming cause, but its emissions based on energy sector (mainly electricity generation, manufacturing and transport sector) comes to be a main source of GHG emissions and air pollution (Mir et al., 2016; Purohit et al., 2013).

In energy sector of Pakistan, total fossil fuel consumption in 2012 was 47.96 Mtoe. Out of this 14.19 Mtoe was consumed in the power sector for electricity generation, 13.26 Mtoe in the manufacturing industries, 10.06 Mtoe in the transport sector, 1.24 Mtoe in commercial/institutional sector, 6.46 Mtoe in household sector and 2.75 Mtoe in the agriculture sector (HDIP, 2013; Pak-IEM, 2011). Detailed split by fuel-sector is given in Figure 1.

Activity data for industrial processes is taken from Pakistan Economic Survey (MoF, 2014). This data includes production in mineral, chemical and metal industries of Pakistan. Mineral industry includes production of limestone, cement, soda ash and dolomite while chemical and metal industry includes production of ammonia, urea, iron and steel. The total quantity of cement production in 2012 was 29.56 teragram (Tg) while of limestone, dolomite and soda ash were $1.28,0.17$, and $0.37 \mathrm{Tg}$ respectively (MoF, 2014). In 2012, the production of urea under chemical industry was $4.47 \mathrm{Tg}$ while the amount of iron and steel produced under metal industry was $0.25 \mathrm{Tg}$ (MoF, 2014).

For agriculture sector, the activity data was mainly available from Pakistan Economic Survey and Agricultural Statistics of Pakistan (MoF, 2014; MoNFSR, 2012). This data includes livestock population (dairy and non-dairy cattle, buffalo, sheep, goats, camels, horses, mules, asses and poultry) in Pakistan in 2012 for estimating methane emissions from domestic livestock enteric fermentation and manure management. Likewise, annual crop production data of sugarcane, rice (paddy) and wheat was acquired for estimating methane emissions from field burning of agricultural crop residues (MoNFSR, 2012). Furthermore, data on amount of nitrogen input to soil through synthetic fertilizer application, 
animal waste and crop residue is assimilated for calculating nitrous oxide emissions from agricultural soils (MoNFSR, 2012).

Approximately 4 percent of the total land area of Pakistan is covered by forests, 5 percent of which is protected (Zaman et al., 2012). For LUCF sector, the activity data is taken from Pakistan Economic Survey (MoF, 2014), Food and Agriculture Organization of the United Nations (FAO, 2013) and Agricultural Statistics of Pakistan (MoNFSR, 2012). The data mainly includes area of forest/biomass stock (conifers, riverian, scrub, irrigated plantation and mangroves), non-irrigated area, inland water bodies, commercial harvest for estimating emissions from changes in forest and other woody biomass stocks.

Almost $20 \mathrm{Tg}$ of solid waste is generated annually in Pakistan, with annual growth rate of about 2.4 percent (Lew, 2016). Activity data for the waste sector is taken from Kawai and Tasaki (2016) and Pakistan Economic Survey (MoF, 2014). This data includes annual municipal solid waste (MSW) disposed to solid waste disposal sites for estimating methane emissions from solid waste disposal on land. Likewise, total urban plus rural population data and total industrial output (of fertilizer, sugar, vegetable ghee ${ }^{1}$, paper and textile) is also acquired from Pakistan Economic Survey (MoF, 2014) for estimating methane emissions from domestic, commercial and industrial waste water and sludge handling.

\subsection{GHG emissions by sector}

When the combustion of fossil fuels takes place, the carbon in the fuel oxidizes and emitted as $\mathrm{CO}_{2}$. Moreover, a little amount of carbon is also emitted as $\mathrm{CO}, \mathrm{CH}_{4}$, and non-methane hydrocarbons which are also ultimately oxidized to $\mathrm{CO}_{2}$ in the atmosphere (IPCC, 1997). In 2012, the energy sector in Pakistan emitted approximately 165.13 teragram of $\mathrm{CO}_{2}$ equivalent ( $\mathrm{Tg} \mathrm{CO}_{2}$ eq) due to fossil fuel combustion in electricity generation, manufacturing industries (such as fertilizer, cement, iron and steel), transport, residential (excluding biomass use in residential sector), commercial/institutional, agriculture/fisheries, plus fugitive emissions (from mining and extraction of coal, oil and natural gas).

\footnotetext{
${ }^{1}$ Vegetable ghee is used for cooking and major source of edible oil in Pakistan, India and other south Asian countries. It has trans-fat level of about 50 percent.
} 
Fugitive emissions from coal, oil and natural gas activities are also considered in the energy sector. Out of this $149.73 \mathrm{Tg}$ were emitted as $\mathrm{CO}_{2}, 14.78 \mathrm{Tg} \mathrm{CO}_{2}$ eq as $\mathrm{CH}_{4}$ and $0.62 \mathrm{Tg} \mathrm{CO}_{2}$ eq as $\mathrm{N}_{2} \mathrm{O}$ as shown in Table 2. Figure 2 presents the GHG emissions distribution by source categories from energy sector. Electricity/power sector contribute 28.67 percent GHG emissions followed by manufacturing (22.93 percent), transport (22.69 percent), residential (9.71 percent), commercial (2.85 percent), fugitive (8.00 percent) and agriculture (5.16 percent).

\subsubsection{Fuel Combustion}

\section{Energy industries}

Energy industries primarily include the consumption of fossil fuels for electricity generation. In 2012, the total installed capacity of thermal power plants for electricity generation in Pakistan was 15,454 MW. Coal utilization was negligible ( 0.10 percent of the total fuel mix) for electricity generation whereas oil and natural gas constituted 29.00 percent and 35.20 percent of the fuel mix (HDIP, 2013). Hydro and nuclear contributed the remaining 35.80 percent. The emissions distribution by fossil fuel type is shown in Figure 3 - left panel. Oil combustion for electricity contributed 61.22 percent emissions followed by natural gas (38.28 percent). Total GHG emissions from electricity generation in 2012 are estimated at $47.34 \mathrm{Tg} \mathrm{CO}_{2}$ eq of which 99.80 percent is emitted as $\mathrm{CO}_{2}$ (Figure 3 - right panel).

\section{Manufacturing industries}

All combustion activities supporting mainly the production of cement, brick and fertilizer are included under manufacturing industries. It also contains emissions occurring during the production of coke used for steel manufacturing (HDIP, 2013). It does not include evaporative emissions occurring at the refinery during refining of petroleum products, such emissions are described discretely under fugitive emissions source category. In Pakistan, it is assessed that 59 billion fired bricks are yearly produced through various sorts of kilns, utilizing various types of fuels and fuel mix like indigenously produced lignite coal, rice husk and other agricultural residues, rubber tires, plastics and different industrial waste, which are ultimately producing highly toxic gases. It is assessed that brick kiln sector consume just about 40 percent of the total extraction/mining of around $4 \mathrm{Tg}$ of locally produced coal, i.e. 1.6 Tg per 
annum (SAARC, 2012). Pakistan's fertilizer production capacity is over 6 Tg per year, and the main fuel use for fertilizer production is natural gas. Total fertilizer production of all kinds (urea, super phosphate, ammonium nitrate, and nitro phosphate) in Pakistan in 2012 was 5.4 Tg (MoF, 2016).

Pakistan's cement industry contributes considerably in the economy of the country. With 29 cement plants and an annual production of cement over $44 \mathrm{Tg}$, it contributes significantly to the national gross domestic product (MoF, 2016). The major fuel consumption in the manufacturing of cement in Pakistan is coal and about 90 percent of the total coal requirement is being achieved through imported coal (MoF, 2016). Pakistan's iron and steel industry stays little and divided. As per the World Steel Association (WSA), steel use in 2015 was 7.1 Tg in Pakistan, meaning per capita utilization of 37.5 kg (WSA, 2016). Local production (Pakistan Steel Mills and Scrap Melters) is approximately in the range of 3 to $4 \mathrm{Tg}$ (nearly 55 percent), whilst the remaining quantum of around $4 \mathrm{Tg}$ (almost 45 percent) of steel a year is filled by import and ship breaker industries (WSA, 2016). The total $\mathrm{CO}_{2}$ equivalent emissions from fuel combustion in manufacturing industries in 2012 were $37.86 \mathrm{Tg}$, and out of this 42 percent of the emissions were from coal combustion in different industries particularly in the cement production.

\section{Transport}

Transport sector is one of the major consumers of commercial energy in Pakistan. It accounted for about 21 percent of the total final commercial energy consumed (48 Mtoe) and 38 percent of the total petroleum products consumed (19 Mtoe) in the country in 2012. About 78 percent of fuel used in this sector is oil - mainly gasoline and diesel. Compressed natural gas (CNG) and electricity meets the remaining 22 percent requirements of the transport sector (HDIP, 2013). All GHG emissions resulting from combustion of fossil fuel in road transport, aviation, railways, and navigation are included in the transport sector. It has been seen in Pakistan over the last two decades that demand for road transport services, holding share of 13 percent in Pakistan's GDP, has grown manifold (MoF, 2012). In Pakistan, registered road vehicles have increased from 2.71 million in 1990 to 11.77 million in 2012 (Figure 4). Cars and two wheelers represent approximately 82 percent of the total road vehicles in Pakistan (MoF, 2014). In 2012, total fossil fuel (such as petrol, diesel, fuel oil, kerosene, liquefied petroleum gas (LPG), and compressed natural gas (CNG)) consumption in the transport sector of Pakistan is estimated to be 
10.06 Mtoe (HDIP, 2013). Diesel covers 50 percent of total fuel consumed in the road transport sector, followed by gasoline (23 percent) and CNG (22 percent) respectively. The rest (5 percent) constitute of LPG, kerosene and fuel oil (Figure 5 - left panel).

In 2012, GHG emissions from transport sector are estimated at $37.46 \mathrm{Tg} \mathrm{CO}_{2} \mathrm{eq}$, out of which $37.18 \mathrm{Tg}$ emitted as $\mathrm{CO}_{2}, 0.19 \mathrm{Tg} \mathrm{CO}_{2}$ eq as $\mathrm{CH}_{4}$ and $0.09 \mathrm{Tg} \mathrm{CO}_{2} \mathrm{eq}$ as $\mathrm{N}_{2} \mathrm{O}$ (Table 2). The road transport sector released approximately $34.44 \mathrm{Tg} \mathrm{CO}_{2} \mathrm{eq}$, which is 92 percent of the total emissions from the transport sector. In comparison, the aviation sector just emitted 5 percent of the total $\mathrm{CO}_{2}$ equivalent emissions. The rest of the emissions were produced by railways ( 2 percent) and navigation (1 percent) sectors (Figure 5 - right panel). The international bunker fuels emissions (resulting from international marine and air transport) have also been assessed, however these emissions are not considered in the national GHG totals as per IPCC guidelines (IPCC, 1997).

\section{Residential, Commercial/Institutional}

Residential sector consume energy mainly for lighting, cooking, heating and household appliances. Natural gas and LPG are the key sources of cooking by urban households in Pakistan while for rural households in Pakistan biomass fuels (crop residues, fuel wood, and animal dung) continue to be the dominant fuels consumed (Bhutto et al., 2011). The consumption of electricity in residential sector of Pakistan is much higher, about 46 percent of the total electricity produced in the country (HDIP, 2013). The population living in urban households is nearly 38 percent (MoF, 2016), and it consume about threefold energy as compared to the rural households. The rural households rely on minimal commercial energy resources and consume relatively biomass fuels particularly for cooking purposes because of limited financial resources (Rashid and Sahir, 2015). The emissions from use of biomass fuels have also been assessed however these emissions are not considered in the national GHG totals as per IPCC guidelines (IPCC, 1997). The commercial/institutional sector involves activities such as cooking, lighting, space heating and cooling, pumping, running of appliances and equipment. Key energy sources used for this sector includes grid based electricity, diesel, kerosene, LPG, and natural gas.

In 2012, the residential sector emitted $16.03 \mathrm{Tg} \mathrm{CO}_{2} \mathrm{eq}$, of which $14.52 \mathrm{Tg}$ were emitted as $\mathrm{CO}_{2}$, primarily due to fossil fuel combustion in the residential sector (Table 2). $\mathrm{CH}_{4}$ and $\mathrm{N}_{2} \mathrm{O}$ emissions were 
$1.28 \mathrm{Tg} \mathrm{CO} \mathrm{Cq}_{2}$ and $0.23 \mathrm{Tg} \mathrm{CO}_{2}$ eq respectively. The commercial/institutional sector emitted $4.70 \mathrm{Tg}$ $\mathrm{CO}_{2}$ eq, of which more than 99 percent was emitted as $\mathrm{CO}_{2}\left(4.65 \mathrm{Tg} \mathrm{CO}_{2} \mathrm{eq}\right)$.

\section{Agriculture/Fisheries}

Main activities for agriculture/fisheries sector include fuels used in water pumps, grain drying, horticultural greenhouses and other agriculture (stationary combustion) along with fuel combusted in generators and tractors on farm land and in forests (mobile combustion). The total diesel consumed in agriculture sector for stationary as well as mobile combustion in 2012 was 2.72 Mtoe (HDIP, 2013; Pak-IEM, 2011). GHG emissions from the agriculture and fisheries sector are estimated at $8.52 \mathrm{Tg}$ $\mathrm{CO}_{2}$ eq, over 99 percent of the emissions were in the form of $\mathrm{CO}_{2}$ (Table 2).

\subsubsection{Fugitive emissions}

The extraction, production, processing or transportation of fuels such as coal, oil, and natural gas involves substantial quantity of methane emissions to the atmosphere (IPCC, 1997). In 2012, fugitive $\mathrm{CH}_{4}$ emissions for Pakistan are estimated at $13.21 \mathrm{Tg} \mathrm{CO}_{2} \mathrm{eq}$ (Table 2). It constitutes 89 percent of the total $\mathrm{CH}_{4}$ emitted from the energy sector. Methane emissions from both surface as well as underground mining of coal have been estimated by using IPCC default emission factors. Additionally, the estimates combine the emissions occurring through mining and post mining events. The emission factors used for underground mining and post mining are 18 and $2.5 \mathrm{~m}^{3} \mathrm{CH}_{4} /$ ton respectively (IPCC, 1997). The total estimated methane emissions from coal mining and handling in 2012 are estimated at $1.05 \mathrm{Tg} \mathrm{CO}_{2} \mathrm{eq}$.

On the other hand in case of oil and natural gas industries, methane emissions take place because of leakages, evaporation and accidental/unintentional releases that occur in the system (IPCC, 1997; Harrison et al., 1996). Emission factors used for estimating $\mathrm{CH}_{4}$ emissions from oil and natural gas activities are taken as simple averages of IPCC default ranges i.e. for oil production, transport, and refining 2.65 (0.3-5), 0.745, 0.745 (0.09-1.4) t $\mathrm{CH}_{4} / \mathrm{PJ}$ respectively; for gas production, and processingtransmission-distribution 71 (46-96), 203 (118-288) t CH 4 /PJ respectively (IPCC, 1997). Total methane emissions from oil and natural gas activities for the year 2012 are estimated at $12.16 \mathrm{Tg} \mathrm{CO}_{2} \mathrm{eq}$. The activity data for estimating methane emissions from coal production and oil \& natural gas activities is taken from Pakistan Energy Year Book 2012 (HDIP, 2013). The total coal production was 1.62 Mtoe 
while total oil and gas production was 3.30 Mtoe and 32.04 Mtoe respectively in 2012 in Pakistan (HDIP, 2013).

\subsubsection{Industrial processes}

In 2012, the total GHG emissions from industrial processes were $19.41 \mathrm{Tg} \mathrm{CO}_{2} \mathrm{eq} .80$ percent of the total $\mathrm{CO}_{2}$ equivalent emissions from industrial processes were from mineral products followed by chemical industry (17 percent) and metal production (3 percent). Absolute emission estimates by subcategory in the industrial processes are shown in Figure S1 (a). Minerals like, cement production, soda ash, limestone and dolomite use emitted $15.54 \mathrm{Tg} \mathrm{CO}_{2}$ eq GHG emissions, out of which the cement production lead to an emission of $14.73 \mathrm{Tg} \mathrm{CO}_{2} \mathrm{eq}$, limestone \& dolomite use emitted $0.65 \mathrm{Tg} \mathrm{CO}_{2} \mathrm{eq}$ and soda ash use emitted $0.16 \mathrm{Tg} \mathrm{CO}_{2}$ eq. Chemical industry includes GHG emissions produced during the processes involved in the production of chemicals (such as ammonia) and total of $3.28 \mathrm{Tg} \mathrm{CO}_{2} \mathrm{eq}$ was emitted by this sector in 2012. The emissions from metal industry are from production of iron and steel in Pakistan and a total of $0.59 \mathrm{Tg} \mathrm{CO}_{2}$ eq was emitted from this sector which is 3 percent of the total GHG emissions from this source category in the industrial processes sector.

\subsubsection{Agriculture and LUCF sector}

GHG emissions from agriculture are estimated at $161.91 \mathrm{Tg} \mathrm{CO}_{2} \mathrm{eq}$, of which $83.79 \mathrm{Tg} \mathrm{CO}_{2}$ eq is $\mathrm{CH}_{4}$ and 78.12 $\mathrm{Tg} \mathrm{CO}_{2}$ eq is $\mathrm{N}_{2} \mathrm{O}$ in 2012. Enteric fermentation comprised 45 percent of the total $\mathrm{CO}_{2} \mathrm{eq}$ emissions from agriculture sector, 7 percent were from livestock manure management. Crop soils released additional 46 percent of the total $\mathrm{CO}_{2}$ equivalent emission from agriculture sector. The remaining 2 percent of the total emissions form agriculture sector is attributed due to the rice cultivation and burning of crop residue (Figure S1 (b)). Table 3 presents GHG emissions from agriculture and LUCF sector. In 2012, total GHG emissions from LUCF sector were 9.67 $\mathrm{Tg} \mathrm{CO}_{2}$ eq.

Enteric fermentation in livestock released $73.73 \mathrm{Tg} \mathrm{CO}_{2}$ eq. The estimates cover all livestock, namely, cattle, buffalo, sheep, goats, poultry, donkeys, camels, horses and others. Manure management emitted 10.58 $\mathrm{Tg} \mathrm{CO}_{2}$ eq. Rice is an important food and cash crop in Pakistan. Rice accounts 4.9 percent of the value added in agriculture and 1.0 percent of GDP (MoF, 2012). In 2012, the net sown area for rice in 
Pakistan was 2.57 million hectares while the production of the crop was an estimated $6.16 \mathrm{Tg}(\mathrm{MoF}$, 2012). Rice cultivation emitted $2.70 \mathrm{Tg} \mathrm{CO}_{2}$ eq or $0.13 \mathrm{Tg}$ of $\mathrm{CH}_{4}$. The source categories for rice cultivation emission comprise all types of water management performed for rice cultivation, specifically, rained, irrigated, upland rice and deep water. The upland rice is zero emitters and irrigated intermittently flooded fields emit maximum methane per unit area. Burning of crop residue emitted 0.81 Tg $\mathrm{CO}_{2}$ eq $\left(0.024 \mathrm{Tg}\right.$ of $\mathrm{CH}_{4}$ and $0.001 \mathrm{Tg}$ of $\left.\mathrm{N}_{2} \mathrm{O}\right)$. The total $\mathrm{CO}_{2}$ equivalent emissions from rice cultivation and crop residue burning were $3.51 \mathrm{Tg} \mathrm{CO}_{2}$ eq.

The main source for $\mathrm{N}_{2} \mathrm{O}$ emissions in agriculture sector is the use of nitrogenous fertilizers in the agricultural soils such as synthetic or organic fertilizers, and deposited manure. The total $\mathrm{N}_{2} \mathrm{O}$ emissions from agricultural soils in Pakistan is estimated to be $74.09 \mathrm{Tg} \mathrm{CO}_{2} \mathrm{eq}\left(0.24 \mathrm{Tg}\right.$ of $\left.\mathrm{N}_{2} \mathrm{O}\right)$ in 2012. This constituted 46 percent of the total GHG emissions ( $\mathrm{CO}_{2}$ equivalent) from agriculture sector in Pakistan.

\subsubsection{Waste}

In Pakistan, the amount of solid waste generation is assessed in the range between 0.28 to 0.61 $\mathrm{kg} / \mathrm{capita} /$ day and the growth rate for this waste generation is 2.4 percent per year (MoF, 2016; Kawai and Tasaki, 2016). The total GHG emissions from waste sector in 2012 in Pakistan was $10.55 \mathrm{Tg}$ $\mathrm{CO}_{2}$ eq, of which, $8.69 \mathrm{Tg} \mathrm{CO}_{2}$ eq was released as $\mathrm{CH}_{4}$ and $1.86 \mathrm{Tg} \mathrm{CO}_{2}$ eq as $\mathrm{N}_{2} \mathrm{O}$. Municipal solid waste disposal on land is the main source of methane emission in Pakistan; it emitted 73 percent of the total $\mathrm{CO}_{2}$ equivalent emissions from this sector. 27 percent of the emissions occurred from industrial waste water disposal and treatment. Figure S1 (c) displays the absolute amounts of GHG emissions from waste sector along with the division of emissions across its sub categories.

In Pakistan, solid waste disposal in a systematic way is only carried out in the cities. This disposal may result in methane emissions because of aerobic conditions produced due to accretion of waste over the years. Emissions resulted from MSW generation and disposal has been estimated at $7.71 \mathrm{Tg} \mathrm{CO}_{2} \mathrm{eq}$ in 2012. The emissions from waste water disposal in industries and domestic waste water together provide waste water generation emissions which are estimated at $2.84 \mathrm{Tg} \mathrm{CO}_{2} \mathrm{eq}$ in 2012 in Pakistan.

\section{Trends of GHG emissions and mitigation flexibility}


Pakistan's Initial National Communication to the UNFCCC provides assessment of the 1994 GHG emissions. It may be noted that both the 1994 and 2012 assessments have been worked out using the IPCC guidelines for preparation of national GHG inventories. The distinctive key features while comparing the two assessments shows that the total GHG emissions from all sectors in Pakistan have

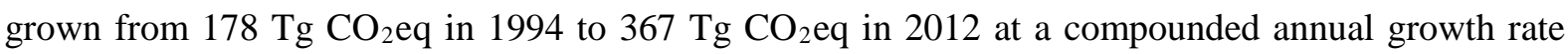
(CAGR) of 4.1 percent. The $\mathrm{CO}_{2}$ emissions have increased from $95 \mathrm{Tg}$ in 1994 to $179 \mathrm{Tg}$ in 2012 for all sectors in Pakistan in 2012 whereas $\mathrm{CH}_{4}$ and $\mathrm{N}_{2} \mathrm{O}$ emissions have grown by 35 and $70 \mathrm{Tg} \mathrm{CO}_{2} \mathrm{eq}$ respectively, between 1994 and 2012. A gas by gas emissions comparative analysis is shown in Table S2 of the supplementary section. Furthermore, a sectoral comparison of the emissions in 1994 and 2012 indicates that the emissions from energy, agriculture and waste have increased at a faster rate as compared to industrial processes and LUCF sectors. The compounded annual growth rates for energy, agriculture and waste sectors are 3.8 percent, 4.6 percent and 4.9 percent respectively. The GHG emissions summary of Pakistan from all sectors in 2012 is provided in Table S3 of the supplement while sectoral shares of emissions are shown in Figure 6. The population in Pakistan in 2012 was 179 million approximately (MoF, 2016). The per capita GHG emission is estimated to be 2.05 tons of $\mathrm{CO}_{2}$ equivalent per capita (Table S4.). As a comparison, population in 1994 was 118 million and the per capita GHG emissions were 1.51 tons of $\mathrm{CO}_{2}$ equivalent per capita (Table S4). Furthermore, total GHG emissions along with emission intensity and compound annual growth rate (CAGR) in 1994 and 2012 is given in Table $\mathrm{S} 4$ of the supplement.

It is observed that large point sources in power and manufacturing industries such as oil and gas based power plants, cement and fertilizer plants, brick kiln, iron and steel etc. contribute a large share (27 percent) of national GHG emissions in Pakistan. Therefore, the national GHG mitigation efforts could be focused primarily on the large point sources as shown in Table S5 of the supplementary section. Improving operation and maintenance $(\mathrm{O} \& \mathrm{M})$ of power plants and reducing transmission and distribution (T\&D) losses in the power sector will be an effective strategy to mitigate GHG emissions. Apparently, T\&D losses from power sector of Pakistan stood at 20.2 percent in 2014 (Khan and Ashraf, 2015). Implementation of energy efficiency measures in energy-intensive industries such as cement, 
fertilizer, pulp and paper, textile etc. would improve industrial productivity and reduce GHG emissions simultaneously. GHG emissions originating from transport sector are widely dispersed across the country and contribute around 10 percent of national GHG emissions. While mitigating GHG emissions from transport sector in Pakistan may be expensive however, including co-benefits (reducing air pollutants and GHG emissions simultaneously) due to air pollution prevention strategies ${ }^{2}$ and low carbon measures $^{3}$ would further enhance the cost effectiveness for transport sector (Amann et al., 2017; WHO, 2011).

Agriculture sector contributes approximately 44 percent to $\mathrm{CO}_{2}$ equivalent GHG emissions of Pakistan. GHG mitigation from agriculture sector requires considerable efforts as the sector is extensively dispersed throughout the country. Mitigation strategies may include crop and grazing land management and pasture improvement, management of organic soils, restoration of degraded lands, livestock and manure management, bioenergy, etc. (Smith et al., 2008). For GHG emissions mitigation in Pakistan, it makes sense to target the largest oil and gas-based thermal plants, largest fertilizer and cement plants as the first step. Energy efficiency improvement measures and provision of renewable energy systems in industrial sector should be initiated for this purpose.

The government energy policy states that all domestic sources of energy, including coal, hydro, natural gas, wind and solar will be fully harnessed in bridging the power sector supply shortfall. The government plans to achieve an optimal mix of coal, gas and hydro potentials as long-term solution to present energy crisis (MoPDR, 2014). The planned addition to the total installed capacity and prescribed energy mix will recognizably have an impact on the projected emissions of the energy sector. With regard to climate change, switching to renewables (particularly solar) instead of the planned coal thermal power generation (Woods, 2017) could lead to air quality improvement and GHG mitigation. In order to narrow the widening gaps between supply and demand of electricity and subsequently ensure

\footnotetext{
${ }^{2}$ Improving fuel (diesel/gasoline) quality and sticker vehicle emission norms (such as EURO standards).

${ }^{3}$ Transition to lower-carbon fossil fuels, biofuels, CNG and hybrid/electric vehicles; Shifting away from the use of individual cars to mass transport modes; reducing the need for travel through land-use planning, as well as improving fuel and vehicle efficiency.
} 
reliable electricity supplies, the country needs to proceed gradually towards sustainable electricity for the nation in near future.

\section{Conclusion and future perspective}

For the year 2012, GHG emission inventory (including $\mathrm{CO}_{2}, \mathrm{CH}_{4}$ and $\mathrm{N}_{2} \mathrm{O}$ ) for Pakistan is developed in this study. Total GHG emissions from different sectors of economy are estimated at $367 \mathrm{Tg} \mathrm{CO}_{2} \mathrm{eq}$. For Pakistan, the per capita $\mathrm{CO}_{2}$ equivalent emissions remained less than half of the world's average per capita GHG emissions in 2012. A comparison of the 1994 and 2012 GHG emission from Pakistan shows that even if GHG emissions in Pakistan during this eighteen year period have increased at an annual rate of 4.1 percent and yet anticipated to increase more for meeting the national developmental goals (MoPDR, 2014; Pak-IEM, 2011), the per capita emissions in Pakistan will however remain low when compared with the global average.

It may be notable that in order to have robust GHG emission inventory, the tier of methodology used would be the key component to be considered. Higher the tier of methodology employed, the emission inventory would be more country representative. As mentioned above we have used IPCC tier 1 default methodology to develop GHG emission inventory for Pakistan primarily due to absence of countryspecific emission factors and emission inventory measurement systems. For improving the inventory emission estimations, there is a need to move up the tier ladder i.e. towards using tier 2 or tier 3 methodologies. Considering the uncertainty for emission factors, default emission factors actually indicate a kind of compromise between the input activity data and the levels of detail necessary to generate the most precise emission estimates. Default methods are considered often as simplifications, and may possibly present huge ambiguities into a national emission estimate. On the other hand, input activity data is directly related to the economic activity in the country. Therefore, it is inclined to have lower uncertainties as national agencies that collect and publish such data frequently may already assess the data uncertainties during their data collection processes.

In order to employ the higher tiers for GHG emissions estimation methodology, it is essential for Pakistan to set up a proper institutional arrangement for developing GHG emission inventory periodically. Furthermore, transparent documentation of methodology and data used for emission 
inventory; establishing and documenting comprehensive QA/QC methods; establishing a proper archiving system for inventory; implementing key category analysis; and building an appropriate inventory improvement plan for the next GHG inventory are the key components necessary for a good national inventory system. It is therefore imperative for Pakistan to move from a project-based approach to a more internalized and institutionalized approach for preparing the GHG emission inventories. This will in turn facilitate the well-timed distribution of the essential information and more effective use of available means.

Pakistan's Ministry of Climate Change (MoCC) enacted National Climate Change Policy (NCCP) in September 2012 as legal framework of responses to climate change in the country. Moreover, MoCC built up an implementation framework for the NCCP in November 2013 to indicate middle and long term action plans. Since the framework incorporates partial action plans on GHG emissions estimation and mitigation, a set of applicable provisions on the GHG inventory system can be set up by amending the framework. There must be given an arrangement of major legal provisions inside NCCP, and detailed provisions within the Implementation Framework of the NCCP in order to build up a GHG inventory system in Pakistan. In future, it is clear that Pakistan in this regard may get advantage through creating a sustainable national GHG inventory management system while fully considering the national circumstances and limitations which at the moment is missing in the country. 


\section{References}

Aichele, R., Felbermayr, G. 2013. The effect of the Kyoto Protocol on carbon emissions. Journal of Policy Analysis and Management, 32 (4), 731-757.

Amann, M., Purohit, P., Bhanarkar, A.D., Bertok, I., Borken-Kleefeld, J., Cofala, J., Heyes, C., Kiesewetter, G., Klimont, Z., Liu, J., Majumdar, D., Nguyen, B., Rafaj, P., Rao, P.S., Sander, R., Schöpp, W., Srivastava, A., Harshvardhan, B. 2017. Managing future air quality in megacities: A case study for Delhi. Atmospheric Environment, 161, 99-111.

Bhutto, A.W., Bazmi, A.A., Zahedi, G. 2011. Greener energy: Issues and challenges for PakistanBiomass energy prospective. Renewable and Sustainable Energy Reviews, 15(6), 3207-3219.

CIA. 2016. The World Fact Book 2016. Central Intelligence Agency (CIA), Washington D.C. (Available at: https://www.cia.gov/library/publications/the-world-factbook/geos/print_pk.html)

FAO. 2013. FAOSTAT database collections. Food and Agriculture Organization (FAO) of the United Nations, Rome (Available at: http://faostat.fao.org)

Grunewald, N., Martinez-Zarzoso, I. 2016. Did the Kyoto Protocol fail? An evaluation of the effect of the Kyoto Protocol on $\mathrm{CO}_{2}$ emissions. Environment and Development Economics, 21 (01), 1-22.

Harrison, M.R., Shires, T.M., Wessels, J.K., Cowgill, R.M. 1996. Methane emissions from the natural gas industry- Executive summary, vol 1. EPA-600/R-96-080a. U.S. Environmental Protection Agency, Office of Research and Development, Washington, D.C.

HDIP. 2013. Pakistan Energy Yearbook 2012. Hydrocarbon Development Institute of Pakistan (HDIP), Ministry of Petroleum and Natural Resources, Government of Pakistan, Islamabad.

IPCC. 1997. Revised 1996 IPCC Guidelines for National Greenhouse Gas Inventories [J.T. Houghton, L.G. Meira Filho, B. Lim, K. Treanton, I. Mamaty, Y. Bonduki, D.J. Griggs, and B.A. Callander (eds.)]. Intergovernmental Panel on Climate Change (IPCC), Meteorological Office, Bracknell, UK. 
Kawai, K., Tasaki, T. 2016. Revisiting estimates of municipal solid waste generation per capita and their reliability. Journal of Material Cycles and Waste Management, 18(1), 1-13.

Khan, S., Ashraf, H.F. 2015. Analysis of Pakistan’s Electric Power Sector. Department of Electrical Engineering, Blekinge Institute of Technology, Sweden (Available at: https://www.divaportal.org/smash/get/diva2:917526/FULLTEXT01.pdf accessed on 15/05/2015).

Lew, R. 2016. Solid Waste Management in Pakistan. Bioenergy Consult - Powering clean Energy Future (Available at: http://www.bioenergyconsult.com/solid-waste-management-in-pakistan/ accessed on 19 April 2017).

Mir, K.A., Purohit, P., Goldstein, G.A., Balasubramanian, R. 2016. Analysis of baseline and alternative air quality scenarios for Pakistan: an integrated approach. Environmental Science and Pollution Research, 23 (21), pp 21780-21793, doi: 10.1007/s11356-016-7358-x.

MoF. 2012. Pakistan Economic Survey (2011-12). Ministry of Finance (MoF), Government of Pakistan, Islamabad (Available at: www.finance.gov.pk/survey 1112.html)

MoF. 2013. Annual Report 2012-13 (State of the Economy). Government of Pakistan, Islamabad (Available at: www.sbp.org.pk/reports/annual/)

MoF. 2014. Pakistan Economic Survey (2013-14). Ministry of Finance (MoF), Government of Pakistan, Islamabad (Available at: www.finance.gov.pk/survey_1314.html).

MoF. 2016. Pakistan Economic Survey (2015-16). Ministry of Finance (MoF), Government of Pakistan, Islamabad (Available at: $\underline{\text { www.finance.gov.pk/survey_1516.html) }}$

MoNFSR. 2012. Agriculture Statistics of Pakistan 2012. Ministry of National Food Security and Research (MoNFSR), Government of Pakistan, Islamabad.

MoPDR. 2014. Pakistan - Vision 2025. Ministry of Planning, Development and Resources, $\begin{array}{llll}\text { Government } & \text { of } & \text { Pakistan, } & \text { Islamabad }\end{array}$ at: http://www.mopdr.com/vision/uploads/vision/pakistan_vision2025.pdf) 
MoPDR. 2015. Annual Plan 2015-16. Ministry of Planning, Development \& Reform (MoPDR), Government of Pakistan, Islamabad.

Pak-IEM Model. 2011. Pakistan Integrated Energy (Pak-IEM) Model: Final report (Volume I). International Resources Group for Asian Development Bank (ADB) and Ministry of Planning and Development (MOPD), Government of Pakistan, Islamabad.

Purohit, P., Munir, T., Rafaj, P. 2013. Scenario analysis of strategies to control air pollution in Pakistan. Journal of Integrative Environmental Sciences, 10 (2), 77-91.

Rashid, T., Sahir, M.H., 2015. Modeling and Analysis of Long Term Energy Demands in Residential Sector of Pakistan. Technical Journal of the University of Engineering and Technology Taxila., 20(3), 11-24.

Rogelj, J., Den Elzen, M., Höhne, N., Fransen, T., Fekete, H., Winkler, H., Schaeffer, R., Sha, F., Riahi, K., Meinshausen, M. 2016. Paris Agreement climate proposals need a boost to keep warming well below $2{ }^{\circ}$ C. Nature, 534 (7609), 631-639.

SAARC. 2012. Evaluating Energy Conservation Potential of Brick Kilns in SAARC Countries. South Asian Association for Regional Cooperation (SAARC) Energy Centre, Islamabad (See: $\quad$ http://www.saarcenergy.org/wp-content/uploads/2016/02/Pakistan-Report-on-Brick.pdf accessed on 19 April 2017).

Seinfeld, J.H., Pandis, S.N. 2006. Atmospheric Chemistry and Physics: From Air Pollution to Climate Change, second ed. John Wiley \& Sons, New York.

Smith, P., Martino, D., Cai, Z., Gwary, D., Janzen, H., Kumar, P., McCarl, B., Ogle, S., O'Mara, F., Rice, C., Scholes, B., Sirotenko, O., Howden, M., McAllister, T., Pan, G., Romanenkov, V., Schneider, U., Towprayoon, S., Wattenbach, M., Smith, J. 2008. Greenhouse gas mitigation in agriculture. Philosophical Transactions of the Royal Society B: Biological Sciences, 363(1492), 789-813. 
Tian, H., Lu, C., Ciais, P., Michalak, A.M., Canadell, J.G., Saikawa, E., Huntzinger, D.N., Gurney, K.R., Sitch, S., Zhang, B., Yang, J. 2016. The terrestrial biosphere as a net source of greenhouse gases to the atmosphere. Nature, 531 (7593), 225-228.

UN. 1992. United Nations Framework Convention on Climate Change. FCCC/INFORMAL/84, United Nations (UN), (Available at: unfccc.int/resource/docs/convkp/conveng.pdf).

UNFCCC. 2003a. Pakistan's Initial National Communication on Climate Change. United Nations Framework Convention on Climate Change (UNFCCC), Bonn (Available at: unfccc.int/resource/docs/natc/paknc1.pdf).

UNFCCC. 2003b. Report of the Conference of the Parties on its Eighth Session, held at New Delhi from 23 October to 1 November 2002. FCCC/CP/2002/7/Add.2, Decision 17/CP.8, United Nations Framework Convention on Climate Change, Bonn (Available at: unfccc.int/resource/docs/cop8/07a02.pdf).

WHO. 2011. Health in the green economy: health co-benefits of climate change mitigation - transport sector. World Health Organization (WHO), Geneva (Available at: $\quad$ www.who.int/hia/examples/trspt_comms/hge_transport_lowresdurban_30_11_2011.pdf accessed on 15/05/2017).

Woods, L.E.J. 2017. China kickstarting new coal boom in Pakistan. (Available at: http://www.climatechangenews.com/2017/03/17/china-kickstarting-new-coal-boom-pakistan/ accessed on 16/05/2017).

WSA. 2015. Steel Statistical Yearbook 2015. World Steel Association (WSA), World Steel Committee on Economic Studies, Brussels.

Zaman, K., Khan, M.M., Ahmad, M., Rustam, R. 2012. The relationship between agricultural technology and energy demand in Pakistan. Energy Policy, 44, 268-279. 


\section{Figure captions}

Figure 1: Fossil fuel consumption by energy sub-sectors in Pakistan for year 2012

Figure 2: GHG emission distribution by source for energy sector

Figure 3: Fuel mix (left panel) and GHG emissions (right panel) from electricity generation

Figure 4: Growth in transport sector of Pakistan ('000 number of vehicles)

Figure 5: Fuel mix (left panel) and GHG emissions (right panel) from transport sector

Figure 6: Sectoral emissions (percent) in 1994 and 2012 GHG inventories 


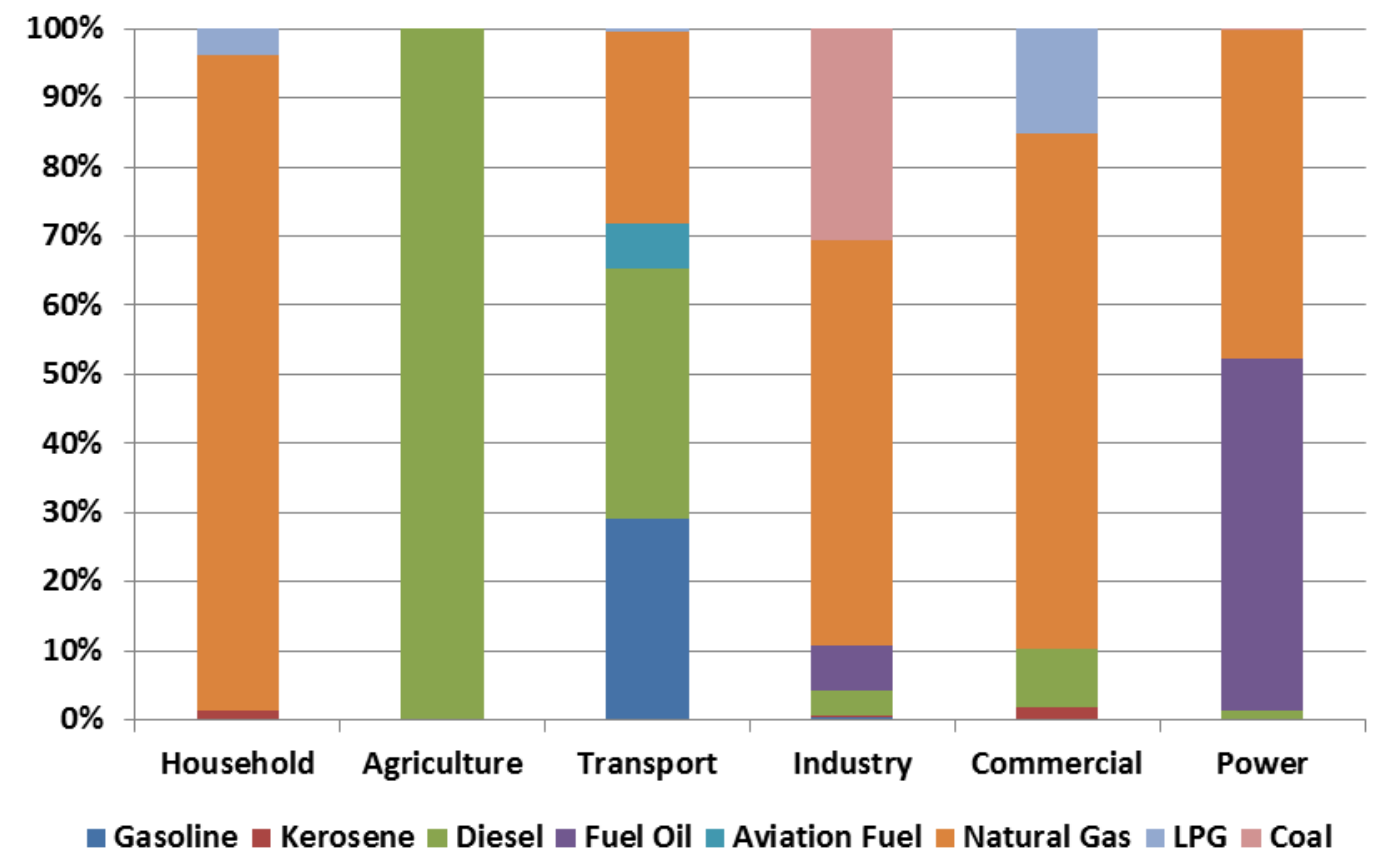

Figure 1: Fossil fuel consumption by energy sub-sectors in Pakistan for year 2012

Source: (HDIP, 2013) 
Total: $165.13 \mathrm{Tg} \mathrm{CO}_{2} \mathrm{eq}$

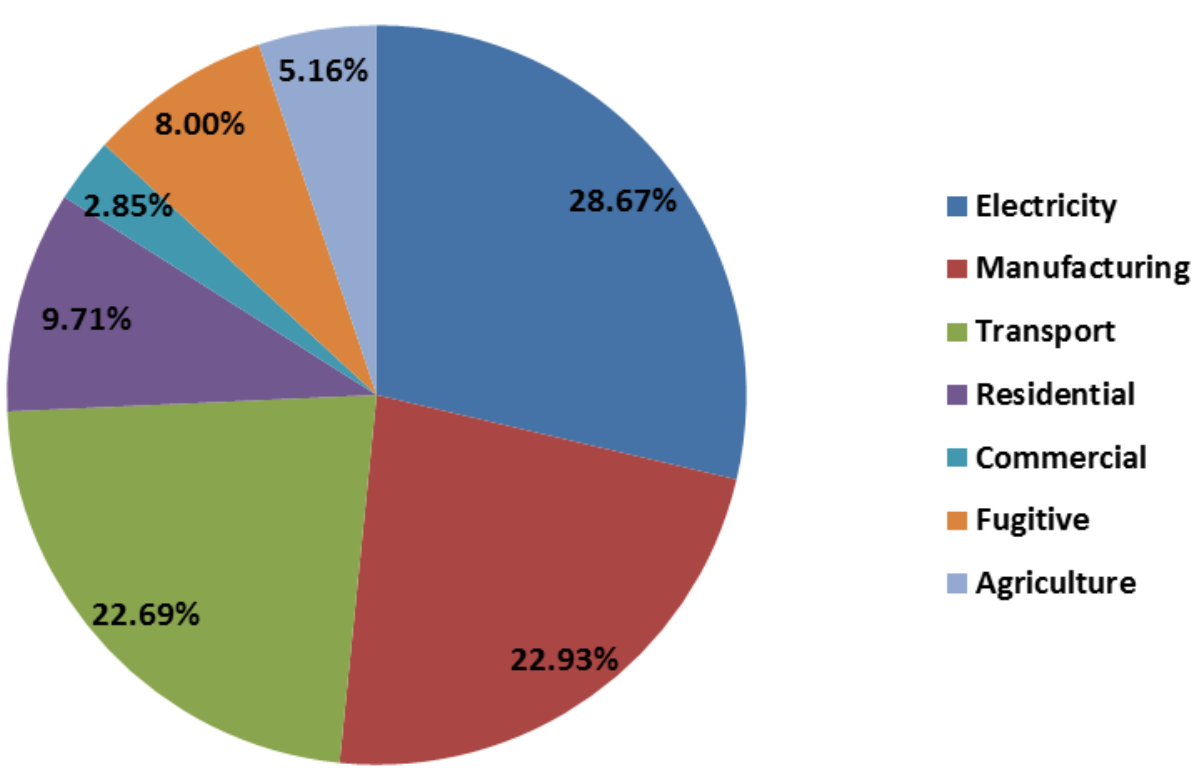

Figure 2: GHG emission distribution by source for energy sector 

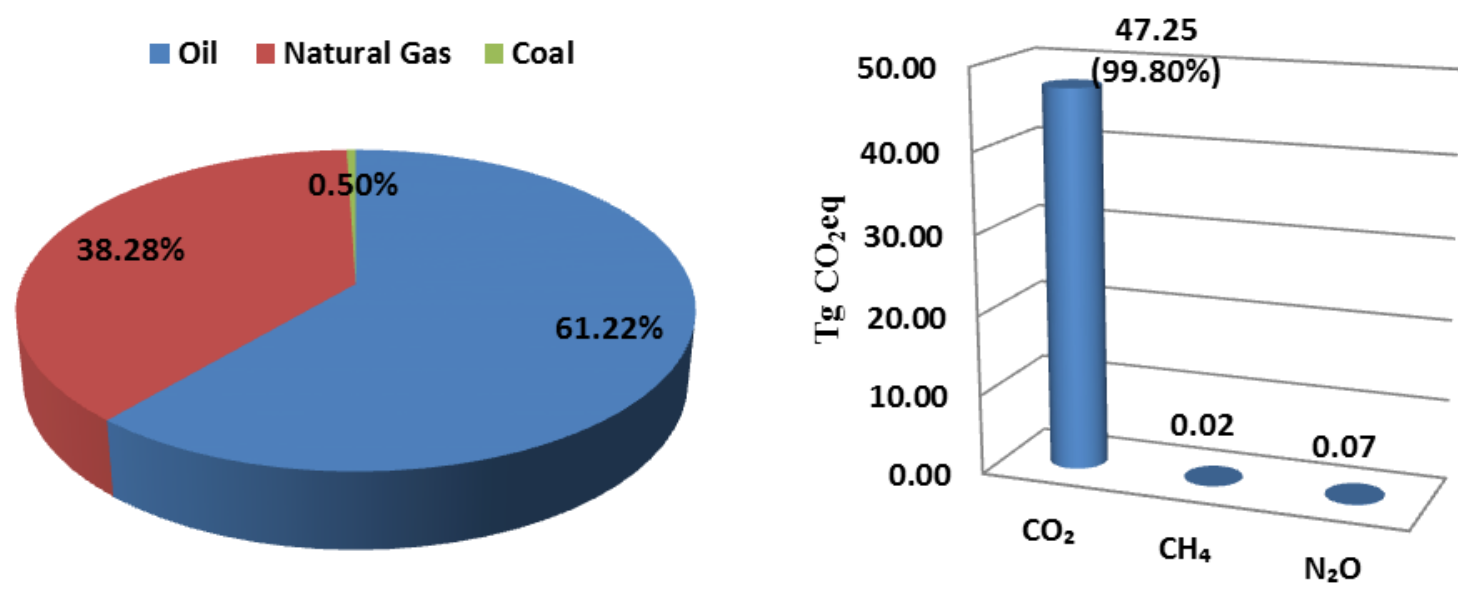

Figure 3: Fuel mix (left panel) and GHG emissions (right panel) from electricity generation 


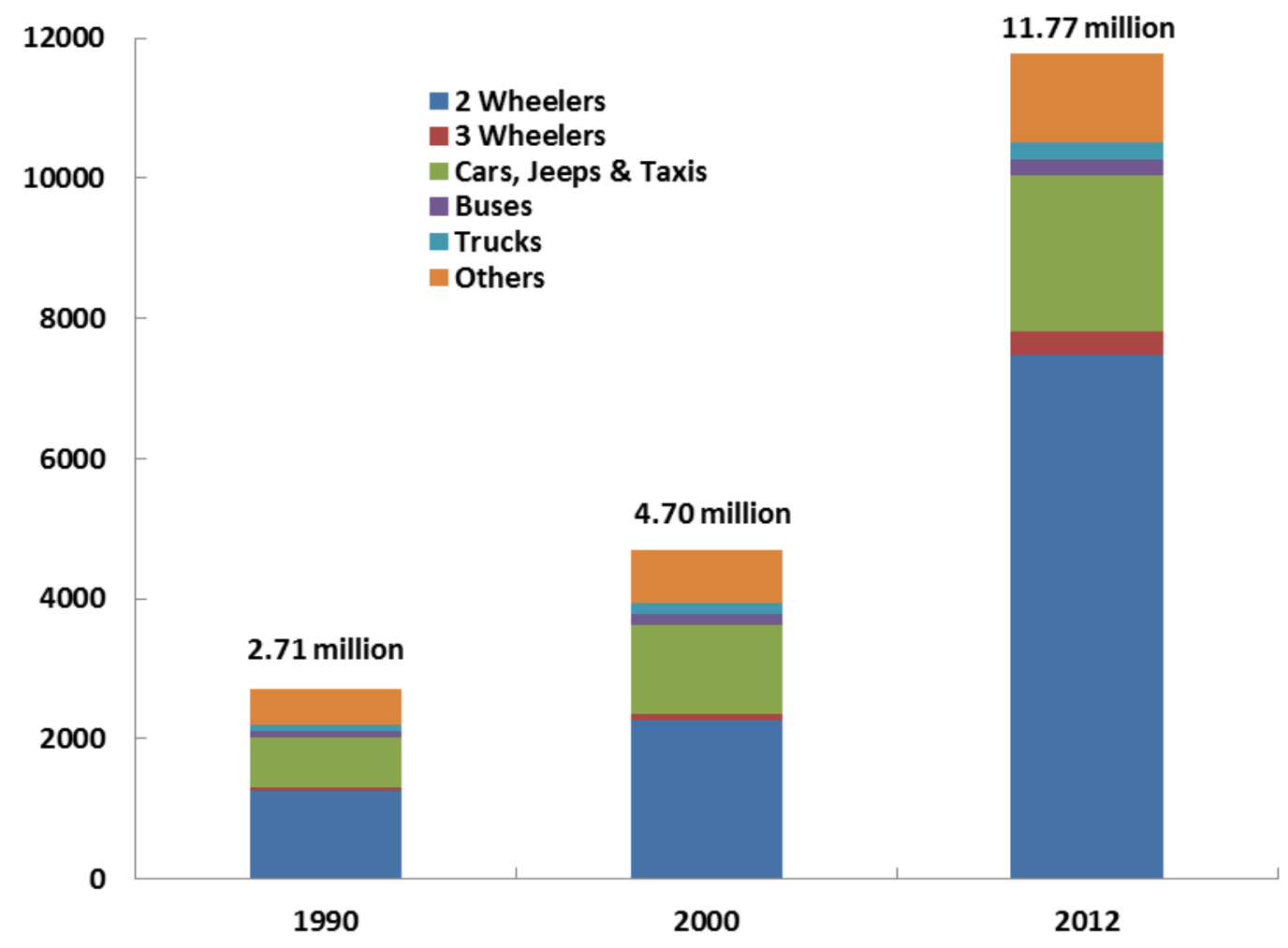

Figure 4: Growth in transport sector of Pakistan (' 000 number of vehicles)

Source: (MoF, 2014) 
Total: 10.06 Mtoe

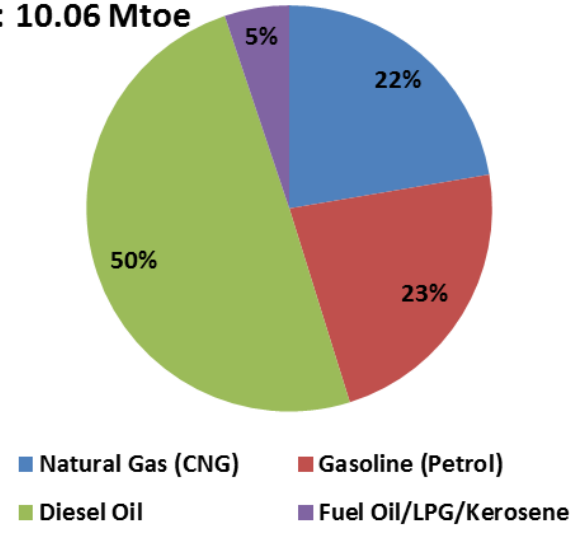

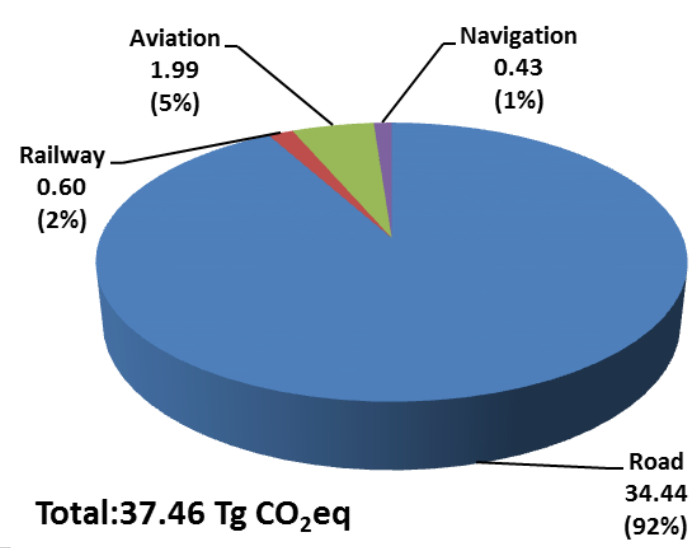

Figure 5: Fuel mix (left panel) and GHG emissions (right panel) from transport sector 

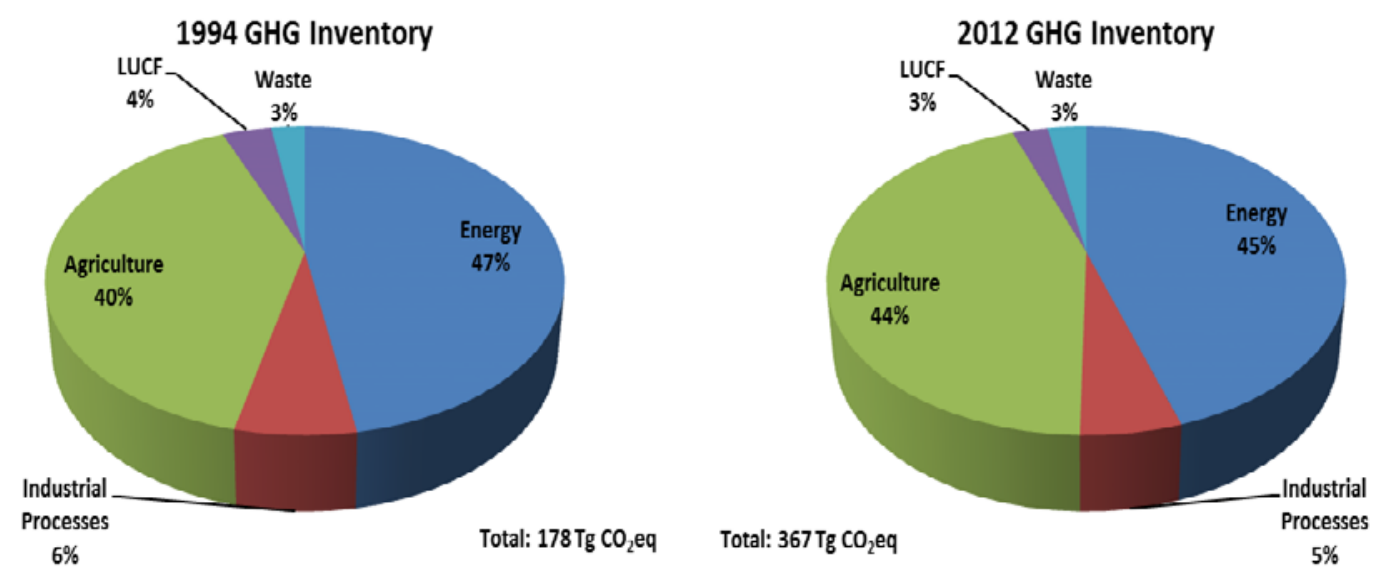

Figure 6: Sectoral emissions (percent) in 1994 and 2012 GHG inventories

Source: (UNFCCC, 2003) 


\section{Table captions}

Table 1: Sectoral classification for GHG emission inventory in all sectors

Table 2: GHG emissions from fossil fuel combustion and fugitive emissions in 2012

Table 3: GHG emissions from agriculture and LUCF sector 
Table 1: Sectoral classification for GHG emissions inventory in all sectors

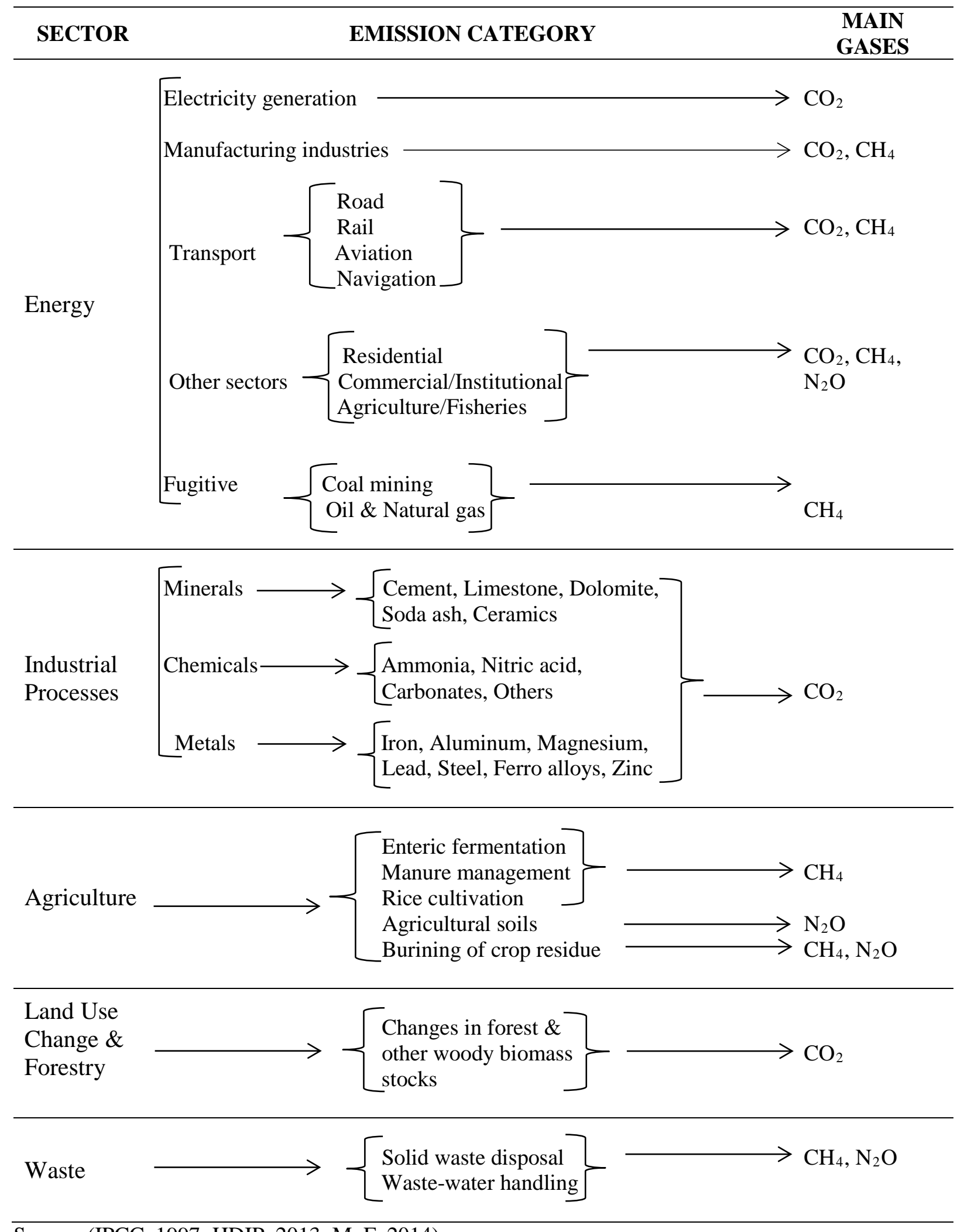

Source: (IPCC, 1997; HDIP, 2013; MoF, 2014) 
Table 2: GHG emissions from fossil fuel combustion and fugitive emissions in 2012

\begin{tabular}{|c|c|c|c|c|}
\hline \multirow[t]{2}{*}{ Source categories } & \multicolumn{3}{|c|}{ GHG emissions ( $\left.\mathrm{Tg} \mathrm{CO}_{2} \mathrm{eq}\right)$} & \multirow{2}{*}{$\begin{array}{l}\text { Total GHG emissions } \\
\qquad\left(\mathrm{Tg} \mathrm{CO}_{2} \mathrm{eq}\right)\end{array}$} \\
\hline & $\mathrm{CO}_{2}$ & $\mathrm{CH}_{4}$ & $\mathbf{N}_{2} \mathbf{O}$ & \\
\hline A. Fuel combustion & 149.73 & 1.57 & 0.62 & 151.92 \\
\hline 1. Energy industries & 47.25 & 0.02 & 0.07 & 47.34 \\
\hline 2. Manufacturing industries & 37.65 & 0.06 & 0.15 & 37.86 \\
\hline 3. Transport & 37.18 & 0.19 & 0.09 & 37.46 \\
\hline Road transport & 34.18 & 0.19 & 0.07 & 34.44 \\
\hline Railways & 0.60 & - & - & 0.60 \\
\hline Aviation & 1.97 & - & 0.02 & 1.99 \\
\hline Navigation & 0.43 & - & - & 0.43 \\
\hline 4. Residential & 14.52 & 1.28 & 0.23 & 16.03 \\
\hline 5. Commercial/Institutional & 4.65 & 0.01 & 0.04 & 4.70 \\
\hline 6. Agriculture/Fisheries & 8.47 & 0.01 & 0.04 & 8.52 \\
\hline B. Fugitive emissions & - & 13.21 & - & 13.21 \\
\hline 1. Solid fuels & - & 1.05 & - & 1.05 \\
\hline 2. Oil and natural gas & - & 12.16 & - & 12.16 \\
\hline Energy sector total $(\mathbf{A}+\mathbf{B})$ & 149.73 & 14.78 & 0.62 & 165.13 \\
\hline
\end{tabular}


Table 3: GHG emissions from agriculture and LUCF sector

\begin{tabular}{|c|c|c|c|c|}
\hline \multirow[t]{2}{*}{ Sectors } & \multicolumn{3}{|c|}{ GHG emissions ( $\left.\mathrm{Tg} \mathrm{CO}_{2} \mathrm{eq}\right)$} & \multirow{2}{*}{$\begin{array}{l}\text { Total GHG emissions } \\
\qquad\left(\mathrm{Tg} \mathrm{CO}_{2} \mathrm{eq}\right)\end{array}$} \\
\hline & $\mathrm{CO}_{2}$ & $\mathrm{CH}_{4}$ & $\mathbf{N}_{2} \mathbf{O}$ & \\
\hline Enteric fermentation & - & 73.73 & - & 73.73 \\
\hline Agricultural soils & - & - & 74.09 & 74.09 \\
\hline Manure management & - & 6.86 & 3.72 & 10.58 \\
\hline Rice cultivation & - & 2.70 & - & 2.70 \\
\hline Agricultural residue burning & - & 0.50 & 0.31 & 0.81 \\
\hline Total Agriculture & - & 83.79 & 78.12 & 161.91 \\
\hline $\begin{array}{l}\text { Changes in forest \& other woody } \\
\text { biomass stocks - Total LUCF }\end{array}$ & 9.67 & - & - & 9.67 \\
\hline Agriculture and LUCF (Total) & 9.67 & 83.79 & 78.12 & 171.58 \\
\hline
\end{tabular}

